\title{
Pengaruh Pemberian Pendamping Makanan Tambahan (PMT) Kepada Ibu Hamil Terhadap Kejadian Kekurangan Energi Kronik Di Wilayah Kerja Puskesmas Salasssae
}

\author{
Asmirati $^{1}$ \\ Mitra Asriani Amin ${ }^{2}$ \\ Andi Muhammad Haerul ${ }^{3}$ \\ Asnidar $^{4}$ \\ ${ }^{1}$ Departemen of Midwife Stikes Panrita Husada Bulukumba, Indonesia \\ ${ }^{2,3}$ Departement of Midwife Stikes Panrita Husada Bulukumba, Indonesia \\ ${ }^{4}$ Departement Keperawatan Anak dan Maternitas, Stikes Panrita Husada Bulukumba, \\ Indonesia
}

Alamat Korespondensi:

Mitra Asriani

Prodi DIII Kebidanan, Stikes Panrita Husada Bulukumba

Mitra.asrianiamin@gmail.com 


\begin{abstract}
ABSTRAK
Gizi pada masa kehamilan adalah salah satu faktor penting yang mempengaruhi perkembangan embrio dan janin serta status kesehatan ibu hamil. Kehamilan merupakan tahapan yang berkesinambungan, sehingga defesiensi pada suatu periode akan memberikan dampak secara berbeda pada outcome kehamilan. Periode perikonsepsional terdiri dari prekonsepsi, konsepsi, implantasi, plasentasi, serta masa embryogenesis. Kualitas bayi yang dilahirkan tergantung pada keadaan gizi ibu sebelum dan selama kehamilan. Tujuan penelitian ini untuk mengetahui pengaruh pemberian biskuit makanan tambahan (PMT) terhadap kenaikan status gizi pada ibu hamil trimester II yang mengalami kekurangan energi kronis. Penelitian ini dilaksanakan di puskesmas Tanete, dan Puskesmas Salassae Kabupaten Bulukumba sulawesi selatan. Rancangan dalam penelitian ini menggunakan Quasi Eksperimen. Variabel independen dalam penelitian ini adalah Pemberian Makanan Tambahan (PMT) kemudian variabel dependen ialah Lingkar Lengan Atas (LILA), variabel kontrolnya ialah Usia,Pendidikan dan paritas. Populasi dalam penelitian ini adalah 165 orang. Analisis Univariat digunakan untuk melihak karakteristik dari masing - masing responden. Analisis bivariat denagn menggunakan uji Wilcoxon sum rank test atau yang lebih dikenal dengan uji mann withney untuk menilai hasil analisis nilai LILA sebelum dan setelah pendampingan pemberian Biskuit PMT. Hasil penelitian: Rerata LILA pada kelompok yang diberikan pendampingan makanan tambahan (PMT) sebelum intervensi adalah 6,33 $\pm 0,32$ dan setelah intervensi meningkat menjadi $8,06 \pm 0,17$ hasil uji statistik secara signifikan $(\mathrm{p}<0,05)$ yang berarti ada perbedaan LILA sebelum dan sesudah pemberian makanan tambahan (PMT). Rerata LILA pada kelompok yang tidak diberikan pendampingan makanan tambahan (PMT) sebelum intervensi adalah sebesar 6,39 $\pm 0,28$ dan setelah intervensi meningkat menjadi $8,73 \pm 0,20$ hasil uji statistik secara signifikan $(\mathrm{p}<0,05)$ yang berarti ada perbedaan LILA sebelum dan setelah kelompok yang tidak diberikan pendampingan.
\end{abstract}

\title{
Kata Kunci : Pendamping makanan tambahan (PMT), Kekurangan energi kronis (KEK), Ibu Hamil
}

\begin{abstract}
Nutrition during pregnancy is one of the important factors that affect the development of embryos and fetuses and the health status of pregnant women. Pregnancy is a continuous stage, so defesience in a period will have a different impact on the outcome of pregnancy. The periconceptional period consists of preconception, conception, implantation, placentation, as well as the period of embryogenesis. The quality of the baby born depends on the nutritional state of the mother before and during pregnancy. The purpose of this study was to find out the effect of supplemental biscuit feeding (PMT) on the increase in nutritional status in pregnant women in the second trimester who experience chronic energy deficiency. This research was conducted at Tanete health center, and Salassae Health Center of Bulukumba Regency in South Sulawesi. The design in this study uses Quasi Experiment. The independent variable in the study was Supplemental Feeding (PMT) then the dependent variable was Upper Arm Circumference (LILA), the control variables were Age, Education and parity. The population in this study was 165 people. Univariate analysis is used to look at the characteristics of each respondent. Bivariate analysis uses the Wilcoxon sum rank test or better known as the mann withney test to assess the results of the analysis of LILA values before and after the assistance of giving PMT Biscuits. Study results: The average LILA in the group given supplemental feeding assistance (PMT) before the intervention was $6.33 \pm 0.32$ and after the intervention increased to $8.06 \pm 0.17$ statistical test results significantly $(p<0.05)$ which means there is a difference in LILA before and after supplemental feeding (PMT). The average LILA in the non \pm 0.20 supplemental food assistance (PMT) group prior to intervention was $6.39 \pm 0.28$ and after the intervention increased to $8.73 \pm 0.20$ statistical test results significantly $(p<0.05)$ meaning there was a difference in LILA before and after the group was not provided with assistance.
\end{abstract}

Keywords: Supplemental food companion (PMT), Chronic energy deficiency (KEK), Pregnant Women 


\section{PENDAHULUAN}

Kebutuhan nutrisi merupakan dasar kesehatan yang baik termasuk gizi pada ibu yang merupakan tantangan yang utama dimasyarakat karena mempengaruhi tidak hanya pada kesehatan perempuan, tetapi juga generasi mendatang, gizi buruk pada perempuan meningkatkan resiko kehamilan yang merugikan tidak hanya untuk ibu tapi juga kepada bayinya. Peningkatkan status gizi pada perempuan dapat meningkatkan kesehatan prekonsepsi, pertumbuhan dan pekerbangan janin menjadi normal sehingga resiko stunting, obesitas, dan penyakit menular dapat teratasi $(H$, Anne, Sophie, \& Oken, 2015).

Salah satu masalah gizi yang dihadapi di indonesia adalah masalah gizi pada masa kehamilan. Gizi pada masa kehamilan adalah salah satu faktor penting yang mempengaruhi perkembangan embrio dan janin serta status kesehatan ibu hamil. Kehamilan merupakan tahapan yang berkesinambungan, sehingga defesiensi pada suatu periode akan memberikan dampak secara berbeda pada outcome kehamilan. Periode perikonsepsional terdiri dari prekonsepsi, konsepsi, implantasi, plasentasi, serta masa embryogenesis (Anizatun dkk, 2015). Kualitas bayi yang dilahirkan tergantung pada keadaan gizi ibu sebelum dan selama kehamilan (Cetin, Berti, \& Calabrese, 2010).

Kebutuhan nutrisi ibu hamil berbeda dengan nutrisi sebelum hamil. Asupan gizi saat hamil meningkat untuk memenuhi kebutuhan janin dan persiapan proses laktasi. Kebutuhan gizi ibu hamil pada setiap trimester berbeda, disesuaikan dengan pertumbuhan dan perkembangan janin serta kesehatan ibu. Pemenuhan kebutuhan gizi pada trimester pertama lebih mengutamakan kualitas dibandingkan kuantitas. Hal ini dikarenakan pada masa ini sedang terjadi pembentukkan sistem saraf, otak, jantung dan organ reproduksi janin, selain itu tidak sedikit ibu yang mengalami gangguan sehingga tidak memungkinkan untuk memenuhi kebutuhan gizi secara kuantitas. Pemenuhan kebutuhan gizi pada trimester II dan III, selain memperhatikan kualitas juga harus terpenuhi secara kuantitas (Susilowati dkk,2016).

Pemberian makanan tambahan pada ibu hamil trimester II meningkatkan berat lahir bayi. Pengaruh PMT terhadap berat lahir bayi akan meningkat jika variabel jarak kehamilan dan jenis kelamin dikendalikan. Perlu dilakukan upaya-upaya yang fokus pada peningkatan berat lahir bayi sehingga kejadian BBLR dapat menurun, yaitu melalui penyuluhan tentang makanan sehat dan bergizi bagi ibu 
hamil serta pemberian tablet $\mathrm{Fe}$ dan monitoring konsumsi tablet $\mathrm{Fe}$ secara teratur sehingga anemia pada ibu hamil dapat dicegah dan risiko BBLR dapat diturunkan(Hana, dkk 2014).

Tujuan penelitian ini adalah untuk mengetahui pengaruh pemberian biskuit makanan tambahan (PMT) terhadap kenaikan status gizi pada ibu hamil trimester II yang mengalami kekurangan energi kronis.

\section{METODE PENELITIAN}

Penelitian ini dilaksanakan di puskesmas Tanete, dan Puskesmas Salassae Kabupaten Bulukumba sulawesi selatan. Rancangan dalam penelitian ini menggunakan Quasi Eksperimen. Variabel independen dalam penelitian ini adalah Pemberian Makanan Tambahan (PMT) kemudian variabel dependen ialah Lingkar Lengan Atas (LILA), variabel kontrolnya ialah Usia,Pendidikan dan paritas.

Populasi dalam penelitian ini adalah 165 orang ibu hamil yang yang berada dipuskesmas Tanete, dan puskesmas Salassae Kabupaten Bulukumba. pengambilan sampel dilakukan secara acak. Untuk menentukan besarnya sampel dalam penelitian ini adalah dengan menggunakan rumus Stanley Lameshow. Berdasarkan rumus tersebut, penelitian ini menggunakan jumlah sampel sebanyak 40 sampel. Jumlah sampel dikeolompokkan menjadi 2 kelompok responden yang diberikan biskuit makanan tambahan dan responden yang diberikan biskuit ikan teri.

Data penelitian yang diperoleh dari responden dengan menggunakan instrument lembar observasi harus melalui empat tahapan yaitu Penyuntingan (Editing), Pengkodean (Coding), Tabulasi (Tabulating) dan entry data.

Analisis Univariat digunakan untuk melihak karakteristik dari masing - masing responden. Analisis bivariat denagn menggunakan uji Wilcoxon sum rank test atau yang lebih dikenal dengan uji mann withney untuk menilai hasil analisis nilai LILA sebelum dan setelah pendampingan pemberian Biskuit PMT.

\section{HASIL PENELITIAN}

Distribusi responden berdasarkan umur. Pada kelompok kontrol yang diberikan Biskuit PMT dari 20 orang responden sebanyak 14 orang (70\%) berada pada kisaran umur 20-35 tahun, 4 orang $(20 \%)$ berada pada kisaran umur $\leq$ 20 tahun, dan 2 orang (10\%) berada pada kisaran umur $\geq 35$ tahun. Sedangkan pada kelompok intervensi berupa pemberian biskuit Ikan teri dari 20 orang responden sebanyak 17 orang (85\%) berada pada kisaran umur 20-35 tahun, 2 orang (15\%) dan pada kisaran umur $\leq 20$ tahun dan 1 orang (5\%) berada pada kisaran umur $\geq 35$ tahun. 
Berdasarkan tabel 1 menunjukkan karateristik pendidikan, pada kelompok kontrol dari 20 orang responden sebanyak 17 orang (85)\% berpendidikan SMA, 2 orang (10\%) berpendidikan SMP, dan 1 orang (5\%) berpendidikan Perguruang tinggi (S1). Sedangkan pada kelompok intervensi dari 20 orang responden sebanyak 12 orang $(60 \%)$ berpendidikan SMA, 6 orang (30\%) berpendidikan SMP, 1 orang $(5 \%)$ berpendidikan SD, dan 1 orang $(5 \%)$ berpendidikan Perguruan tinggi(S1).

Berdasarkan Tabel 1 karateristik Jumlah kehamilan, Pada kelompok kontrol dari 20 orang responden sebanyak 12 orang $(60 \%)$ yang berada pada kehamilan pertama, 5 orang $(25 \%)$ berada pada kehamilan ketiga, 2 orang $(10 \%)$ berada pada kehamilan kedua, dan 1 orang $(5 \%)$ pada kehamilan keempat. Sedangkan pada kelompok intervensi dari 20 orang responden sebanyak 14 orang (65\%) berada pada kehamilan pertama, 72 orang (10\%) pada kehamilan kedua, 2 orang (10\%) berada pada kehamilan 3, dan 1 orang $(5 \%)$ yang mengalami kehamilan kelima.

Berdasarkan tabel 2 merupakan analisis data dengan menggunakan uji wilcoxon untuk mengetahui apakah terdapat terdapat perbedaan yang bermakna antara LILA sebelum dan setelah pendampingan pemberian makanan tambahan (PMT). Uji mann Whitney untuk mengetahui perbedaan yang bermakna antara LILA yang diberikan pendampingan makanan tambahan (PMT) dan tidak diberikan pendampingan makanan tambahan (PMT) .

$$
\text { Rerata LILA 6,33 } \pm 0,32 \text { pada }
$$
kelompok yang diberikan pendampingan makanan tambahan (PMT) dan 6,39 $\pm 0,28$ pada kelompok yang tidak diberikan pendampingan. Hasil uji statistik menunjukkan tidak terdapat perbedaan yang singnifikan $(p>0,05)$ antara kelompok yang diberikan pendampingan makanan tambahan (PMT) dan tidak diberikan pendampingan. Hal ini menunjukkan bahwa LILA sebelum pemberian intervensi pada kedua kelompok sama.

Rerata LILA pada kelompok yang diberikan pendampingan makanan tambahan (PMT) sebelum intervensi adalah $6,33 \pm 0,32$ dan setelah intervensi meningkat menjadi $8,06 \pm 0,17$ hasil uji statistik secara signifikan $(\mathrm{p}<0,05)$ yang berarti ada perbedaan LILA sebelum dan sesudah pemberian makanan tambahan (PMT). Rerata LILA pada kelompok yang tidak diberikan pendampingan makanan tambahan (PMT) sebelum intervensi adalah sebesar $6,39 \pm 0,28$ dan setelah intervensi meningkat menjadi $8,73 \pm 0,20$ hasil uji statistik secara signifikan $(\mathrm{p}<0,05)$ 
yang berarti ada perbedaan LILA sebelum dan setelah kelompok yang tidak diberikan pendampingan, Peneliti melakukan pengurangan nilai setelah dan sebelum intervensi (beda mean) hasil uji mann whitney menunjukkan ada perbedaan beda mean antara yang pendampinagan Pemberian makanan tambahan (PMT) dan tidak dilakukan pendampingan pemberian makanan tambahan dengan nilai $\mathrm{P}$ value 0,000. Hal ini menunjukkan bahwa pendampingan pemberian makanan tambahan mampu menaikkan Lingkar Lengan Atas Ibu Hamil.

\section{PEMBAHASAN}

Pada Kelompok Biskuit makanan Tambahan (PMT) rata-rata IMT Sebelum pendampingan pemberian Biskuit Makanan Tambahan (PMT) 16,65 \pm 2,64 dan ada perbedaan setelah Pendampingan Pemberian Biskuit makanan Tambahan (PMT) sebesar 17,2 \pm 2,91. Teori menjelaskan bahwa penambahan berat badan selama hamil idealnya berbeda-beda setiap orangnya, tergantung dari berat badan sebelum hamil (Sharlin J 2011). Teori tersebut sejalan dengan penelitian Yonky dkk. (2009) yang menunjukkan bahwa status gizi pada kehamilan mempengaruhi Indeks Massa Tubuh ibu selama hamil yang selanjutnya mempengaruhi hasil kelahiran.
Hasil penelitian ini sesuai dengan hasil penelitian Joko Prianto yang menyatakan bahwa terdapat hubungan yang signifikan antara asupan protein dengan pertambahan berat badan ibu hamil. Hasil penelitian ini sesuai dengan teori yang menyatakan bahwa peningkatan kebutuhan protein selama kehamilan akan mempengaruhi pertumbuhan dan perkembangan kandungan

1. Analisis Lingkar Lengan atas sebelum pendampingan pemberian Biskuit PMT dan setelah pendampingan pemberian makanan biskuit PMT

Pada penelitian menunjukkan bahwa rerata LILA pada kelompok yang diberikan pendampingan makanan tambahan (PMT) sebelum intervensi adalah 6,33 $\pm 0,32$ dan setelah intervensi meningkat menjadi $8,06 \pm 0,17$ hasil uji statistik secara signifikan $(\mathrm{p}<0,05)$ yang berarti ada perbedaan LILA sebelum dan sesudah pemberian makanan tambahan (PMT). Rerata kadar protein pada kelompok yang diberikan biskuit ikan teri sebelum intervensi adalah sebesar $6,39 \pm 0,28$ dan setelah intervensi meningkat menjadi $8,73 \pm 0,20$ hasil uji statistik secara signifikan $(\mathrm{p}<0,05)$ yang berarti ada perbedaan LILA sebelum dan setelah pemberian biskuit ikan teri. 
Pada kehamilan terjadi perubahan fisiologis, matabolik, dan juga terjadi peningkatan kebutuhan energi diperlukan untuk pembentukan dan pertumbuhan plasenta dan janin. Apabila energi dalam tubuh tidak tersedia atau tidak digunakan secara maksimal maka akan menyebabkan kekurangan energi sehingga dapat berpengaruh terhadap keberlangsungan proses kehamilan (Casanueva dkk,2013).

Memperbaiki status gizi ibu yang sedang hamil dengan pendampingan pemberian Biskuit PMT yang merupakan program pemerintah pangan yang diberikan secara gratis dan menjadi suatu Alternatif perbaikan gizi pada ibu hamil terutama didarah Kabupaten Bulukumba.

\section{KESIMPULAN DAN SARAN}

Berdasarkan hasil penelitian pengaruh pendampingan pemberian makanan tambahan (PMT) pada ibu hamil trimester II kekurangan energi kronis maka dapat disimpulkan bahwa Terdapat perbedaan nilai LILA sebelum dan setelah pemberian biskuit PMT sebanyak 1,73 gr/dl, Pendampingan Pemberian biskuit PMT meningkatkan LILA sebanyak 8,73 g/dl dibandingkan tidak dilakukan pendampingan pemberian biskuit PMT dengan nilai LILA 8,06 gr/dl.

Adapun saran yang bisa penulis berikan Bagi petugas kesehatan atau bidan agar melakukan pemantauan lebih dan perbaikan gizi terhadap ibu hamil khususnya ibu hamil yang mengalami kekurangan energi kronis agar kehamilan dapat berlangsung normal dan tidak berlanjut pada komplikasi kehamilan dan memastikan Biskuit PMT terdistribusi dengan baik dan tepat sasaran.

Bagi tenaga kesehatan khususnya bidan diharapkan untuk bisa melakukan edukasi pentingnya Biskuit makanan tambahan bagi pemenuhan nutrisi pada ibu hamil, sehingga ibu hamil termotivasi untuk mengomsumsi ikan teri sebagai pangan lokal yang mudah didapatkan.

\section{DAFTAR PUSTAKA}

Abraham.S, M. Gebremeskel, S. Shumye.(2015). Magnitude of chronic energy deficiency and its associated factors among women of reproductive age in the Kunama population, Tigray, Ethiopia, in 2014. BMC Nutrition (2015) 1:12 DOI 10.1186/s40795015-0005-y.

Adawiyah R. 2007. Pengolahan dan Pengawetan Ikan. Jakarta: Bumi Aksara

Arfiyanti.(2013). cookies ikan gabus sebagai makanan tambahan untuk ibu hamil trimester II. departemen kimia,fakultas kedoktenan universitas indonesia.artikel.jakarta

Aini, N.(2009). Lebih Jauh Tentang Sifat Fungsional Telur. Dikases: Tanggal $12 \quad$ April 2019. http://kulinologi.biz/index.php 
Albugis,D.(2008).Faktor-Faktor Yang mempengaruhi Berat Bayi Lahir. Penelitian.UI.Jakarta

Anna.W.P.(2011). Pengaruh Faktor Usia Tehadap Keluaran Maternal dan Perinatal dan Perinatal Pada Persalinan Primigravida di RD Dr.Kariadi Semarang Priode Tahun 2010.Artikel Penelitian. Program Pendidikan Sarjana Kedokteran.FK Universitas Diponegoro. Semarang

Azizah.A, A.Merryana.(2017). Tingkat Kecukupan Energi Protein Pada Ibu Hamil Trimester Pertama dan Kejadian Kekurangan Energi Kronis. Media Gizi Indonesia, vol.12, No. 1 Januari-juni 2017 : halaman 21-26. Departemen Gizi kesehatan, Fakultas Kesehatan Masyarakat, Universitas Airlangga, Surabaya.

Almatsier, S. (2010). Prinsip Dasar Ilmu Gizi Cetakan Kesembilan. (PT \& G. P. Utama., Eds.). Jakarta.

Almatsier.S.2002. Prinsip Dasar Ilmu Gizi.Penerbit PT Gramedia Pustaka Utama. jakarta

Arisman.(2009). Gizi Dalam Daur Kehidupan Edisi 2. Jakarta: Penerbit Buku Kedokteran EGC.

Arisman.(2004). Gizi Dalam Daur Kehidupan. Jakarta: Penerbit Buku Kedokteran EGC.

Arisna,

dkk. (2010).Asuhan Kebidanan.Cet.I.Yogyakarta.Grah a Ilmu

Cetin.I, Berti.C, Calabrese.S.( 2009). Role of micronutrients in the periconceptional period. Human Reproduction Update, Vol. 16, No. 1, Halaman : 80-95. http://doi.org/10.1093/humupd/d $\underline{\mathrm{mp} 025}$

Casanueva R. and Viteri F.R.(2013). Iron and Oxidative Stress in Pregnancy. J Nutr ;133(33).1700S-1708SHana, dkk 2014).

Escott-Stump, Sylvia.(2008).Nutrion and Diagnosis_Related Care Sixth Edition. USA:Lippincott Williams \& Wilkins

Fatmala.A.I, Adi.C.A. (2017). Daya terima dan kandungan protein biskuit substitusi tepung ubi jalar ungu dan isolat protein kedelai untuk pemberian makanan tambahan ibu hamil kek. Program studi s1 ilmu gizi. Fakultas kesehatan masyarakat, universitas airlangga .surabaya

Susilowati, Kuspriyanto.(2016). Gizi Dalam Daur Kehidupan. Bandung : PT Refika Aditama

Prianto, J. 2006. Hubungan antara Asupan Energi dan Protein dengan Kenaikan Berat Badan Ibu Hamil di Kabupaten Gunungkidul Yogyakarta. (Karya Tulis Ilmiah). Universitas Gadjah Mada. YogyakartaSharlin J 2011).

Youngky.dkk.(2009). Status Gizi Awal Kehamilan dan Pertambahan Berat Badan Ibu Hamil Kaitannya dengan BBLR. Jurnal Gizi dan Pangan. 4(1): $8-12$. 
Tabel 1. Distribusi responden Berdasarkan karateristik (Umur, Pendidikan, dan Jumlah Kehamilan)

\begin{tabular}{lcccc}
\hline \multirow{2}{*}{ Karateristik } & \multicolumn{3}{c}{ Kelompok } \\
\cline { 2 - 5 } & $\mathbf{N}$ & $\mathbf{\%}$ & $\mathbf{N}$ & Intervensi \\
\cline { 2 - 5 } & & 20 & 2 & 15 \\
\hline Umur & 4 & 17 & 77,5 \\
20-35 Tahun & 14 & 70 & 1 & 7,5 \\
$\geq$ 36 Tahun & 2 & 10 & & \\
Pendidikan & & & 1 & 5 \\
SD & 0 & 0 & 6 & 30 \\
SMP & 2 & 10 & 12 & 60 \\
SMA & 17 & 85 & 1 & 3 \\
S1 (Sarjana) & 1 & 5 & & 70 \\
Jumlah Kehamilan & & & 14 & 10 \\
Kehamilan 1 & 12 & 60 & 2 & 10 \\
Kehamilan 2 & 2 & 10 & 2 & 3 \\
Kehamilan 3 & 5 & 5 & 1 & 5 \\
Kehamilan 4 & 1 & 5 & 1 & $\mathbf{1 0 0}$ \\
Kehamilan 5 & 0 & 0 & $\mathbf{2 0}$ & \\
\hline Total & $\mathbf{2 0}$ & $\mathbf{1 0 0}$ & & \\
\hline
\end{tabular}

Tabel 2. Hasil analisis nilai LILA sebelum dan setelah pendampingan pemberian Biskuit PMT

\begin{tabular}{llccc}
\hline \multirow{2}{*}{ Variabel } & \multicolumn{2}{c}{ LILA } & Selisih & P value \\
\cline { 2 - 3 } & \multicolumn{2}{c}{$\begin{array}{c}\text { Pre } \\
\text { Mean } \pm \text { SD }\end{array}$} & $\begin{array}{c}\text { Post } \\
\text { Mean } \pm \text { SD }\end{array}$ & \\
\cline { 2 - 4 } Pendampingan & $6,33 \pm 0,32$ & $8,06 \pm 0,17$ & $1,73 \pm 0,36$ & $0,000^{\mathrm{b}}$ \\
\hline $\begin{array}{l}\text { Tidak } \\
\text { Pendampingan }\end{array}$ & $6,39 \pm 0,28$ & $8,73 \pm 0,20$ & $2,34 \pm 0,33$ & $0,000^{\mathrm{b}}$ \\
\hline P value & $0,416^{\mathrm{a}}$ & $0,000^{\mathrm{a}}$ & $0,000^{\mathrm{a}}$ & \\
\hline
\end{tabular}

